\title{
Building an African Identity through Magical Realism: Cyclicality in Ben Okri's The Famished Road
}

\author{
Connor Powers
}

Dr. Bryan Conn (Mentor and Co-editor)

The independence movements that secured the autonomy of African nations resulted in the need for African writers and artists to create important new voices for Africa. Thus, beginning in the 1940s and 50s, African authors sought to rewrite the common perceptions of Africa and African culture, as well as establish a wholly independent African identity. In an interview in 1985, Chinua Achebe, the Nobel Prize winning Nigerian author, described the atmosphere of the time as one of rediscovery: "We had a story to tell, we were a different people, we must tell this story, and we insist on being listened to" (Jefiyo 141). Colonialism and European authors had long created an image and identity of Africa, one of a "dark continent" and one that was entirely devoid of cultural identity and a meaningful heritage. With reference to such contexts, this study seeks to illustrate the place of "Magical Realism" in Nigerian writer, Ben Okri's The Famished Road (1991). We shall observe that its assumptions stand in stark political and aesthetic contrast to the more conventional Literary Realism of Chinua Achebe.

In creating a new identity, spiritual or otherwise, one must make decisions about cultural representation. In realist works like Chinua Achebe's Things Fall Apart (1958), the ways of representing a culture can be, in many ways, limited to presenting readers with descriptions of how life once was and what it became after colonialism and had imparted identities based in the given or directly perceivable social relations. Achebe is clear in showing the changes of a society through the introduction of Christianity and forms of European commerce like the trading store. He contrasts those phenomena and their legacies with explanations of traditional religious values and customs, as well as with the way the overall society functioned before colonialism. In other words, authors like Achebe are limited by realism to talking about identity in a nationalistic sense, as the cultural critic K. Anthony Appiah notes:

"These early novels seem to belong to the world of eighteenth- and nineteenthcentury literary nationalism; they are theorized as the imaginative recreation of a common cultural past that is crafted into a shared tradition by the writer.... The novels of this first stage are thus realist legitimations of nationalism." (Appiah 15)

To form a new identity in a realist context thus requires Achebe to adopt a nationalistic attitude to express how colonialism has changed his culture. Achebe is caught up in exposing the differences between the Europeans and the Africans in order to present the new way of life that Nigerians underwent due to colonialism.

Nevertheless, it is not fair to reduce Achebe to a purely nationalistic writer or to claim that his only intention is to make a 
political statement; there are certainly deeper themes in Things Fall Apart. Speaking on the subject of Nigeria, Achebe mentions that he is highly critical of the country but that "it's my country and since, as I said, providence put me here, my role is to make this place more habitable than I met it" (Jefiyo 147). But it is important to point out that due to the then-popular issue of creating an independent nation, the idea on many people's minds would have been that of national identity. With regard to such concern, the mimetic nature of realist novels lends itself to a discussion about topics of the time and how those influenced then-contemporary culture and beliefs. From this vantage point, we are able to discern that Achebe is just as much commenting on nationalism as he is making a nationalistic statement himself. However, all of this shows the issues that can arise with attempting to establish an identity in only realist terms. Much more goes into a culture and identity than just the political status of a group or their autonomy.

In The Famished Road Okri further explores the idea of what African identity means in a postcolonial world by eschewing real-world politics at times, and in other cases by tying politics to a larger, more spiritual world beyond national borders. He is just as interested in establishing a new identity for newly independent African nations but does so with the use of Magical Realism and an exploration of how spiritual and political identities intersect. By Magical Realism, I refer to the capacity to see spiritual phenomena in everyday occurrence. In many ways, Okri departs from Achebe's numerous distinctions of life before and after colonization to view colonization as one of many spiritual iterations and lives through which Nigeria has lived. As opposed to viewing change as something that can forever make a culture or country disappear, as Achebe does, change is constant in Okri's world and it is something that he deems necessary or, at the very least, inevitable.

\section{Why Magical Realism}

In using Magical Realism to depart from earlier literary realist traditions, Okri is not only creating his own, unique view of Nigerian identity but he is tapping into a literary tradition that has long been used in colonialized cultures. He thereby distances himself from European influence. Though Magical Realism as a concept carries European roots (Guenther 34) and early, European Magical Realist novels do exist, the genre was completely transformed in post colonized Latin America. In explaining why, one scholar argues that "The indigenous resources from which magic was derived were frequently utilized as a tool for the region's self-definition. The autochthonous was a means through which to recuperate a buried identity and culture" (Sasser 7). Magical Realism became a tool for colonized authors to reestablish their cultures and identities; and in becoming that, Magical Realism has gained its own identity as a mode that is strongly influenced by cultures that have often been pitted against more dominant ones of the West.

Via Magical Realism, Okri is able not only to recuperate his buried Nigerian identity but also to evoke his culture and traditions. By contrast Achebe's Literary Realism, must approach the recuperation of his culture and identity in terms that sooner evoke European and the West. Unlike Okri, Achebe is not pitting his culture against Western ideas but is placing culture within those ideals and declaring it to be equal. One commentator argues that "Achebe must reinscribe what, by imperial contingency, has become the language of literary modernity in order that his reclamation of African 
humanity will have conventional authority and legitimacy" (Korang 7).

Magical Realism allows Okri to assert Nigeria's identity on his own terms and push back against Western ideas of what Nigerian culture is, while Achebe coopts Western literary norms in order to make the case for Nigeria's equality in terms of culture.

\section{Establishing Identity in The Famished Road}

From the very opening lines of The Famished Road it is very clear that similarities and stark differences exist in what both Ben Okri and Chinua Achebe are attempting to do with their respective novels. The novel starts with the lines, "In the beginning there was a river. The river became a road and the road branched out to the whole world. And because the road was once a river it was always hungry" (Okri 3). The term "In the beginning" thus mimics the famous opening lines of the Bible. Already we can see a difference in the style and worldview between Okri and Achebe. By evoking European outlook in his allusion to the most influential text in western literature, Okri suggests the influence colonialism has had on African art and thought. He nonetheless creates a new African identity that is not only political or national but also spiritual or religious. We also get a bit of Okri's view on how the past is always affecting the present; for, as the river evolved or changed into a road, it did not lose its principal characteristics, instead the "hunger" of the river persisted.

From different perspectives, then, both Okri's and Achebe's novels intersect in their exploration of how colonialism has affected the African identity. Things Fall Apart is very much a reaction to the works of European authors such as Joseph Conrad, who, to Achebe's mind, perpetuated Western ideas about Africa and its cultures. As a result, much of the reason that the Achebe's novel uses literary realism is as a rebuke of Conrad's and other European's views. Achebe is making a statement by offering an unvarnished and accurate view of Africa, as Korang notes: "In another orientation, Achebe is a post-Eurocentric writer who revokes and reworks the aesthetic models that his Eurocentric predecessors have otherwise confined to the fixing and reaffirmation of the West as sole or exclusive possessor of humanistic common sense" (Korang 2). Achebe utilizes realism as it allows him to be equal to European authors and it allows him to take the very same aesthetic modes that created the idea of the "dark continent" and contradict those beliefs.

If Achebe's use of literary realism is a reaction against European writers' creation of a narrative of Africa that is inaccurate, then such backdrop serves to illustrate why Okri chose to use magical realism in response to many of the same issues. Because magical realism attempts "to capture the paradox of the unity of opposites" (Cooper, 1), Okri is better able to approach the upheaval that colonization caused in Nigeria. In other words, colonization has created a tension in African literature and culture between heritage and the modern world. Instances of old beliefs and cultural practices that the Europeans attempted to stamp out are always coming to the surface and often clash with the demands of modernity. This tension may explain why The Famished Road so quickly alternates between depictions of extreme poverty and the constant pull the narrator, Azaro, feels from the spirit world.

The "unity of opposites" that magical realism allows, gives Okri more freedom to express the mindset of the post-colonized Nigeria. Specifically, it allows Okri to introduce one of the main themes of the 
novel-that of rebirth. Abiku or spiritchildren, is the true nature of the main character, Azaro. His "children" are characterized as having lived many lives and by the fact that they "are strange ones, with half of our beings always in the spirit world." (4) Azaro is thus constantly stuck between the real world and the issues it brings and his past lives and his connections to the supernatural spirit world. As a result, he is forced to see the world through a different view than that of everyone else in his community; his efforts to distance himself from the spirits only lead to their attempting to bring him back.

The concept of Abiku is critical in The Famished Road. Forced to live between two states of being, Abiku morphs Nigeria's culture in the modern, post-colonial world. Azaro's only friend Ade, who is also an Abiku, begins telling him, "Our country is an Abiku country. Like the spirit-child, it keeps coming and going. One day it will decide to remain. It will become strong. I won't see it" (478). Here, Okri presents the idea that colonialism has not ended in Nigeria. Instead it has led to another life, one that will continue on and become something different and eventually greater.

This approach to history and culture invites a markedly different stance than one experiences in Things Fall Apart, which makes the case that what was once Nigeria has been destroyed. Oknokwo, the main character, is unable to reconcile his beliefs with what happens in the novel. Achebe remarked once that Okonkwo is "betrayed" by the culture, for it must disappear and often be replaced. (Achebe 143) But in The Famished Road, the changing of a culture is not betrayal; "Dad," Azaro's father, views the ever-changing nature of Nigeria as a strength, as something that must occur, just as the lives of Abiku are ever changing.

\section{The Role of Madame Koto}

Okri presents us with his view of culture and history as being cyclical. The presence of traditional spirits in a modern, colonized Nigeria is just one example of Okri's cyclical view of culture. If we look at the character of Madame Koto, a bar owner and often antagonizing figure towards Azaro, for example, we see her transform the material conditions of her life; yet her role in society and her social status in general remain the same. The life of Madame Koto is a mystery throughout the novel, as even "the spirits were curious about her" (75). Madame Koto owns what seems to be the only bar in town, yet at the start of the novel it is regularly empty save for the flies and geckos. The location of her bar itself is subject to constant change - at one point, the bar moves "deep into the forest and all her customers were animals and birds" (59). Koto's bar acts as both a bridge between the town and the forest, which is often the border between the real and spirit worlds, the developed and the past, and as a bridge between the poor and the wealthy in the town. All of this reflects back on Madame Koto herself who, in the novel, undergoes great changes in her status in the community.

In the beginning of the novel, and to an extent throughout, Madame Koto is regarded as a witch. "Madame Koto's face was smudged. She looked like a washed out monster, a cross between a misbegotten animal and a wood carving. 'She's a witch' one of the creditors said." (91) Azaro is often confused and frightened by the things that Koto does and says and is curious about her room into which no one is ever allowed to peer. But Madame Koto is also one of the most dynamic characters in the novel. She begins to give up her spiritual practices and becomes involved in one of the novel's two 
political parties - the aptly named "Party of the Rich." Earlier on, Koto's bar is always empty save for the clientele made up of demonic and grotesque spirits who stream into it. All of this leads to the spirits' attempting to kidnap Azaro until he grabs a fetish and buries it deep in the forest (133).

This scene marks a turning point for Madame Koto. For one, we do not see her again for a while as Azaro "feared her anger" (141); but we also apprehend a change in the community that frequents the bar. The spirits do no come back. Instead, Madame Koto begins hosting parties for political elites and the wealthy and even hires prostitutes to help draw in customers. Upon noticing this Azaro remarks, "I knew we were in the divide between past and future. A new cycle had begun, an old one was being brought to a pitch, prosperity and tragedy rang out from what I saw, and I knew that the bar would never be the same again" (220). We come back to the idea of cycles and the moving from one age to a next. Though the bar was never going to be the same again, its role remains constant. The shift in Madame Koto and her bar shows us that a connection to the past and, more obviously, to the spirit world has been severed; but the narrative likewise suggest that new groups and secular ideas have taken root.

As for the relation of such dynamics to the effects of colonialism, I suggest that Okri's use of magical realism differentiates his view of the changes that Nigerian culture and identity have undergone over time. Whereas Achebe suggests that cultures can change completely-we also infer that they can "betray" those who most ardently follow its rules - Okri implies that a culture does not necessarily change. Rather, its aesthetics do. If we examine the character of Madame Koto further, we get a sense that, while her material condition does change, she still abandons traditions, though her role in the community endures. At the beginning of the novel she is regarded as a witch and avoided; but even after she marries and involves herself in the Party of the Rich she is treated as an outcast by the community that supports the Party of the Poor: "When she entered the room everyone fell silent. This also included those who didn't even know who she was.... She looked at everyone and everyone avoided looking at her. She had changed. Her face had become big and a little ugly... She had become more severe, more remote, more powerful" (360). Though her material status improves, her social standing does not. Magical realism here features a "unity of opposites." Most would assume that the removal of the spirits and the rejection of all things magical would alter one's life, but for Madame Koto it does not. Okri is unifying the two opposing forces of spirituality and politics and remarking that they are more similar than not. Similarly, even modernity has its own mythology, since everything that is new will eventually become tradition; Okri illustrates as much via the non-evolution of Madame Koto to show that.

Okri is certainly not excusing colonialism or washing away its legacy. If we again look at Madame Koto's character, we can see that, while her standing in the community does not improve as a result of her success, she does suffer negative effects. Namely her appearance degrades and Okri describes her in much harsher language. As noted above, her face had become "a little ugly" and "There was a patch of rough darkened skin on her face which made her expressions sinister" (360). By succumbing to political corruption, Madame Koto physically suffers. Azaro remarks, "For the first time I saw that she had changed. She was now wholly enveloped in an invisible aura of power, a force-field of dread" (371). Greed and corruption become physical ailment in Okri's world; they act as spirits do, and 
Madame Koto even confesses, "I am not happy" (371).

Although Madame Koto seemingly trades her connection with the spirits in favor of corrupt politicians, the spirits do not entirely leave her, as suggested by Okri's tying the two together. Corrupt politics act as their own spirits in a sense, they give Koto a dreadful aura and dictate her life to the point of unhappiness. She is also inflicted with evil spirits at the same time and she becomes pregnant with three Abiku.

"And I saw that Madame Koto was pregnant with three strange children. Two of them sat upright and the third was upside down in her womb. One of them had a little beard, the second had fully formed teeth, and the third had wicked eyes. They were all mischievous, they kicked and tugged at their cords, they were the worst type of spirit-children, and they had no intention of being born." (464)

Here, Okri again mixes the literal with the metaphorical and the real with the magical. On one hand Madame Koto is literally pregnant with evil Abiku triplets, a burden she most likely was forced assume to gain her new wealth. But in a metaphorical sense, we can read Madame Koto's pregnancy as a metaphor for how corruption is brought into a country, it is "born" from people wanting to make their material lives better. Koto is sick of the way people in the community had treated her and the repeated fighting that would end in her bar being wrecked. As a result, she searches for new opportunity only to become even more ostracized and allow the corrupt Party of the Rich to influence the town. In addition, Okri is tying real-world political corruption to magical beliefs, again to highlight the way the aesthetics of a culture change while its underlying issues remain constant. As one commentator notes, "Gradually Madame Koto's instability, and the roots of the political corruption, tend towards the Abiku image of circularity, universality and repetition, rather than on change, transgression and third time" (Cooper, 106).

\section{Reconnecting with the Past}

There is, however, a desire for change within the novel itself. Dad, for instance, is the character most fed up and tired with his current material condition. Yet, lacking education, there is not much that he can do to change his future. This is another instance of Okri's showing how the details of a culture do not actually change: with the coming independence one would expect opportunity for all, but in reality changes will only come to a few. Dad, lacking many skills, gets left out and in his frustration declares himself a political independent. In his attempts at bettering his life, Dad is left with virtually no options, since independence did not shift social dynamics as we also saw with Madame Koto. Dad therefore decides to become a boxer, as he had once been.

There are noticeable similarities here between Dad and Okonkwo. For one, both men were famous for their physical capabilities. In Things Fall Apart Achebe even begins the novel by introducing us to Okonkwo through his past wrestling exploits: "Okonkwo was well known throughout the nine villages and even beyond. His fame rested on solid personal achievements" (3). Okonkwo is described as having beaten Amalinze the Cat, a man who never fell on his back, in a wrestling match. Similarly, Dad is said to have been a famous boxer named Black Tyger and that "He beat up all the young men" (69). Both men have gained some status in their respective societies through physical feats; but that is considered a thing of the past. For Dad, he was cursed to lose his next fight and, to save himself from 
the embarrassment, leaves his village for the city. In Things Fall Apart, Okonkwo proves himself to be a great fighter and wrestler, but those are skills that are hardly needed in peaceful times which make up the setting of the novel's beginning. In this case there seems to be more of an agreement among the two authors about the traditions of fighting. What once made both of the men famous and highly regarded is looked upon as nothing more than a fading legacy.

However, we do get some differences that once again emerge from Okri's use of magical realism. Okonkwo makes a final stand against the colonization of his community by dressing in his old war garb and attempting to use force to drive out the Christian missionaries. This proves to be useless as the only man he ends up killing is a Nigerian convert: "Okonkwo stood looking at the dead man. He knew that Umuofia would not go to war. He knew because they had let the other messengers escape. They had broken into tumult instead of action." (116) In the end, his actions do nothing to change the outcome, as physical violence cannot overcome bureaucracy and we are left with the idea that colonialism is more powerful than traditions.

However, with Dad we get a different outcome to his return to boxing. Dad begins to shadow box and train day and night, which brings crowds to see him; people are interested in the tradition. He is more of a novelty than anything but there is a sense of excitement and magic around him that is not present for Okonkwo. Further the mere fact of Dad's boxing presents new positives for Azaro. He explains, "The night became safer for me. And while he trained I would wander our road. When he was around the night turned everything familiar into another country, another world. What a new place the night made the ghetto!" (353). Okri is showing the reintroduction of traditional ideas of manhood; a reconnection with traditions changes the present. It is again going back to Okri's belief in the cyclical nature of culture, as past traditions can become an almost magical thing; and within the novel, magic literally occurs when the first man Dad fights after becoming Black Tyger is a ghost, although the fight takes a physical toll on Dad, who is badly hurt, taking over six days to recover. But the fight is a turning point; as Azaro says, "I could smell the fists of Yellow Jaguar on his spirit. I could smell Dad's rebirth in advance" (358).The fight gives a sense of power to the existence of spirits and to traditions; they are able to harm but still transform the world.

\section{Conclusion}

Okri's use of magical realism to present us with the idea of a living past exhibits his belief in the cyclical nature of culture and politics. People who are outcasts usually remain that way despite material changes; people stuck in poverty reach out and connect with traditions for a means of escape; and the new elites merely create the same sort of havoc as the spirits once did. The history of a country is cyclical purely because of what Okri outlines in The Famished Road. Okri is looking past these aesthetic changes, like Madame Koto's financial status or the power of political parties, and instead illustrates that the day-to-day life of Nigeria has remained mostly the same. The presence of the spirits never goes away, nor does Okri suggest they ever will.

But this still leads us to the question of what Okri thinks of the cyclicality. If Okri is using traditional Nigerian folklore imagery and blending it with modern social and political issues, it is important to question the purpose of doing so. If culture is truly cyclical, is that good or bad? What should be done? One commentator argues that, 
"Okri is also attempting to depict the necessity of breaking the abiku stranglehold. This necessity, and what a struggle it is to achieve, is reinforced throughout the narrative by the repeated attempts that are made on Azaro to abduct him back to his abiku dimension... The hope of the novel lies in Azaro successfully repudiating the abiku within himself and thereby, denying the inevitability of that mythical, Tutuolan road...."

She is certainly correct in pointing out that there is a duality when it comes to the spirits, as Azaro has positive and negative reactions with them. At one point he is threatened that spirits with an increasing number of heads will come in pursuit of him, showing that the spirits do indeed have nefarious intentions and dislike the fact that Azaro is living among normal people (Cooper, 302-3). There is a sense, as suggested, that Azaro is fighting against the spirits. Nevertheless, Cooper may go too far in claiming that Okri sees the cycles of history as something that must be simply fought against. I sooner suggest that Okri's position is more nuanced. Although the novel registers a desire to escape of the restraints of the spirit world and to control one's destiny, it also insists on the impossibility of that task. Okri suggests that Nigeria is an Abiku nation in the previously quoted speech by Ade, which presents us with the difficulty in completely breaking free from the spirits. After all, breaking free from spiritual connections would mean that Nigeria would lose a connection with its past and its culture, in the same way that Azaro is in danger of abandoning the spirits. It is certainly important to change and move forward, as we can see through Azaro's struggles; but to imply that one can completely overcome them would suggest that a nation like Nigeria would need completely to surrender its ties to the past.
It is also important to contrast Ade to Azaro. Ade chooses to die after being injured; he thus returns to the spirit world to live once again in another life, as all Abiku do. There is a serenity to him that Azaro does not have. Ade is able to see the future and tell him as much:

"There will be changes. Coups. Soldiers everywhere. Ugliness. Blindness. And then when people least expect it a great transformation is going to take place in the world. Suffering people will know justice and beauty. A wonderful change is coming from far away and people will realise the great meaning of struggle and hope. There will be peace. Then people will forget. Then it will all start again, getting worse, getting better. Don't fear. You will always have something to struggle for, even if it is beauty or joy." (478)

This is a much more positive view of the cycle of history. There is an acknowledgement of the bad that will happen, though Ade suggests that it is worthwhile and that struggles will always give us something for which to fight. Okri's view toward the cycle of history is that it is important to move on and attempt a break from it but also to acknowledge that to do so is often impossible. Ade represents the hope that Okri has for Nigeria as well as the importance of being connected with the past, while Azaro represents the often difficult reality that these ideas cause.

When we come back to the idea of how African writers sought to create a new identity and what they wanted it to look like, Okri's cyclical view stands out. In a sense, Okri is not creating a new identity for Africans but simply acknowledging that the past cannot be accessed in the same way, since it is still with us in the present. Engaging with it will not bring us forward. In 
other words, colonialism has come and gone and with its old ways of life, while its new identity has already been created. But the new identity is still mixed with the old. For example, when the cosmopolitan members of Party of the Rich are attending a party held by Madame Koto, they engage in the same kind of chaotic revelry that the spirits once did in her bar, Azaro remarks, "In the terrible heat of the dance I saw that... among them all, there were strangers to the world of the living" who "danced as men and women when in fact they were the dead, spirits and animals in disguise" (459-60). Those that are meant to be the new powers of the country are, instead, the same as the old.

I must note that some part of the difference in the views about colonialism of Achebe and Okri derives from the time periods in which they were writing. Given that Things Fall Apart was written just prior to Nigerian independence, it is understandable that Achebe held the view that the future presented a new path forward and that they were "different people" as mentioned in the introduction. As a result, it is clear why Achebe utilized Literary Realism as a way of asserting Nigeria as an equal to European cultures; it is a cornerstone of British literature and Achebe is able to make a bold statement in contradiction of European beliefs about Africans. But Okri has the advantage of writing well over thirty years post-independence and as a result saw the following corruption that plagued the country in the $20^{\text {th }}$ century. It no doubt bore a heavy influence on Okri's world view. With that said, it still needs to be argued that Okri's use of magical realism is what enables him to present us with that world view. Achebe is forced to discuss the past and present through distinctions, much like the way he discusses the influence colonialism had on Africa. But in The Famished Road the past can become something living, a physical force that effects the present. Bringing the past to influence the future is uniquely powerful and is what makes Okri a great contrast to Achebe; as Achebe remarks, "But our imagination is faulty. Now, we may never be allowed to correct our imagination before we are overtaken by something else. This is the tragedy of it." (144) He is acknowledging that changing the future and current perceptions of a culture is an often fruitless endeavor because something new will always come along and change it itself. Okri can move beyond this by allowing the past to become an entity that overtakes one's imagination.

Magic gives power to abstract concepts and ideas, it gives it a physical impact. This enables authors in formerly colonized cultures to explore and give voice to that which has been thought abandoned, forgotten, and destroyed by the institution of colonialism. Though both Achebe and Okri attempt to give an independent voice to Africa, there is a unique ability within Okri's writing, due to his use of magical realism, to imbue that voice with power. Such power forces us to confront it, even if the goal is ultimately that of moving on from it. In talking about Ben Okri and the Latin American author Miguel Asturias' use of magical realism, Christopher Warnes writes that, "Both writers begin from an awareness that narrative realism is inadequate to their purposes, for it is perceived as distancing writers and readers from much that is important in the cultures they are trying to describe" (147). It is this "distancing" that Okri is able to forego in The Famished Road precisely because he uses magical realism. In creating an identity, one needs to create the culture; for Okri this occurs amidst magical realism.

\section{Works Cited}


Achebe, Chinua. Things Fall Apart, edited by Francis Abiola Irele. Norton, 2009.

"Adichie in Dialogue with Achebe: Balancing Dualities in Half of a Yellow Sun." Research in African Literatures, vol. 47, no. 3, Fall 2016.

Appiah, Kwame Anthony. "Is the Post- in Postmodernism the Post- in Postcolonial?" Critical Inquiry, vol. 17, no. 2, 1991, pp. 336-357. JSTOR, www.jstor.org/stable/1343840.

Accessed 5 Apr. 2020.

Andrade, Susan Z. "The Problem of Realism and African Fiction." Novel: $A$ Forum on Fiction, vol. 42, no. 2, Summer 2009

Aizenberg, Edna. "The Famished Road: Magical Realism and the Search for Social Equity." Yearbook of Comparative Literature, vol. 43, 1995

Cooper, Brenda. Magical Realism in West African Fiction. Routledge, 1998.

Hogan, Patrick Colm. Empire and Poetic Voice. SUNY Press, 2006.

Korang, Kwaku Larbi. "Making a PostEurocentric Humanity: Tragedy,
Realism, and Things Fall Apart." Research in African Literatures, vol. 42, no. 2, Summer 2011,

Morrison, Jago. "Tradition and Modernity in Chinua Achebe's African Trilogy." Research in African Literatures, vol. 49, no. 4, 2018,

Okri, Ben. The Famished Road. New York, Doubleday, 1993

Quayson, A. (1994). Realism, Criticism, and the Disguises of Both: A Reading of Chinua Achebe's Things Fall Apart with an Evaluation of the Criticism Relating to It. Research in African Literatures, 25(4), 117-136.

Sasser, Kim A. Magical Realism and Cosmopolitanism: Strategizing Belonging. Palgrave Macmillan, 2014.

Warnes, Christopher. Magical Realism and the Postcolonial Novel: Between Faith and Irreverence. Palgrave MacMillan, 2009.

Zamora, Lois P, and Wendy B. Faris. Magical Realism: Theory, History, Community. Durham, N.C: Duke University Press, 1995. Print. 